\title{
Hinweise Fur Autoren - Instructions To Authors
}

Infusionstherapie 1992;

Ethische und rechtliche Voraussetzungen: Zur Publikation eingereichte Manuskripte müssen bei Untersuchungen an Probanden oder Patienten die Erklärung enthalten, daß das

Versuchsprotokoll von einer Ethik-kommission genehmigt wurde und somit den ethischen Standards der Deklaration von Helsinki 1964 entspricht. Gleichzeitig ist die Einwilli-gung der Versuchsperson nach Aufklärung im Text des Manuskriptes zu fixieren. Hinweise, die auf die Identität der Versuchsperson schließen lassen, sind zu vermeiden.

Tierversuchsvorhaben bedürfen gleichfalls der Genehmigung und müssen den Forderungen des Tierschutzgesetzes in seiner Fassung von 1986 entsprechen. Auf diese Genehmigung ist im Manuskript hinzuweisen. Arbeiten, die nicht aus der Bundesrepublik Deutschland stammen, müssen einen vergleichbaren Hinweis tragen.

1. Allgemeines, Verlagsrecht

Bitte senden Sie Ihr Manuskript direkt an den Verlag S. Karger, z.Hd. Frau Anne Schieber, Postfach 1724, D-8034 Germering/ München.

Beiträge erscheinen als Übersichtsarbeiten, Originalarbeiten, lau-fende klinische Studien, Kurzmitteilungen, Kasuistiken, klinisch-pathologische Konferenzen, Kongreßberichte, Informationen für die Klinik und Briefe an die Herausgeber.

Originalarbeiten, laufende klinische Studien und Kurzmitteilungen sollten in englischer Sprache abgefaßt werden. Alle anderen Beiträge können wahlweise in deutscher oder englischer Sprache ein-gereicht werden.

Das Manuskript soil in satzreifem Zustand in dreifacher Ausfertigung eingereicht werden. Die Entscheidung über die Aufnahme erfolgt aufgrund mehrerer Gutachten. Eine Kopie des Manuskripts soil grundsätzlich beim Autor verbleiben.

Typographische Gestaltung und redaktionelle Bearbeitung sind dem Verlag vorbehalten.

Die Arbeit darf nicht gleichzeitig bei einer anderen Publikation eingereicht sein. Es ist Sache des Autors, die Nachdruckerlaubnis für Abbildungen, Tabellen usw. aus anderen Publikationen zu beschaffen. Mit der Annahme des Manuskriptes zur Publikation ge-hen alle Rechte auf den Verlag über. Ohne schriftliche Genehmigung des Verlages dürfen diese Publikationen oder Teile daraus nicht in an-dere Sprachen übersetzt oder in irgendeiner Form mit mechanischen oder elektronischen Mitteln (einschließlich Fotokopie, Tonaufnahme und Mikrokopie) reproduziert oder auf einem Datenträger oder einem Computersystem gespeichert werden.

Geschützte Markennamen müssen mit einem hochgestellten ${ }^{\circledR}$ be-zeichnet werden. Die Verantwortung für die korrekte Befolgung die-ser Vorschrift liegt ausschließlich beim Autor. 2. Manuskripte

Diese sollen in li/2-zeüigem Abstand geschrieben sein, links und rechts einen angemessenen breiten Rand aufweisen und (einschließlich Titelseite und Literaturverzeichnis) kontinuierlich durchnume-riert sein. Folgende Gliederung wird empfohlen:

Titelseite mit Titel und Kurztitel der Arbeit in Deutsch und Englisch; Autorenangabe; Institutsangabe in der Landessprache der Autoren. 
Zusammenfassung und Schlüsselwörter in Deutsch und Englisch. Zu-sammenfassungen sollen 20 Schreibmaschinenzeilen nicht überschrei-ten. In die Zusammenfassung gehören keine Literaturzitate, Tabellen, Abbildungen und Abbildungs- und Tabellenhinweise sowie allgemein gehaltene Aussagen. $\mathrm{Zu}$ einer Arbeit gehören 3-5 Schlüsselwörter.

Textseiten der Arbeit mit Gliederung in Einleitung, Material und Me-thoden (oder: Patientengut und Methoden), Ergebnisse, Diskussio-

nen. Fußnoten (gegebenenfalls numeriert) am unteren Rand jeder

Textseite.

Abkürzungen bitte möglichst sparsam verwenden. Bei speziellen Abkürzungen jeweils beim ersten Auftreten das Wort ausschreiben und 1:99-100

Ethical and legal prerequisites: Manuscripts handed in for publication dealing with examinations of probands and patients must include the declaration that the trial protocol has been approved by an ethical committee and thus meets the standards of the Declaration of Helsinki (1964). At the same time the probands' informed consent has to be included in the manuscript. Informations suitable to reveal the proband's identity are to be avoided.

Planned animal experiments demand consent as well and must meet the requirements of the laws protecting animals in the version of 1986. A reference to this approval must be included in the manuscript. Articles from outside the FRG have to include a comparable notice.

1. General Remarks - Publishing Laws

Please send your manuscript directly to S. Karger Publishers, Attn.: Mrs. Anne Schieber, P.O. Box 1724, D-8034 Germering/ Munich (FRG).

Contributions are classified as review articles, original papers, ongoing clinical studies, short communications, casuistic contributions, clinical pathological conference, congress reports, clinical information and letters to the publisher.

Original papers, ongoing clinical studies and short communications should be written in English. All other contributions may be handed in optionally in German or English.

The manuscript should be submitted in triplicate, ready for printing. Acceptance of a manuscript is based on the evaluation by several referees. The author should always keep a copy of the manuscript. The publisher reserves the right to edit the manuscript and decide on the layout. The manuscript is received with the understanding that it is not under simultaneous consideration for publication elsewhere. It is the authors responsibility to obtain permission to reproduce illustrations, tables etc. from other publishers. Once the manuscript is accepted for publication, all the rights will be retained by the publisher. The publication, or parts of it, may not be translated into other languages, or reproduced by any mechanical or electronic means (including photocopying, recording and microcopying), or stored in a retrieval system without the publisher's written permission. Registered trade names must be marked with the superscript registration symbol ${ }^{\circledR}$. It is the sole responsibility of the author to ensure that this rule is followed properly.

2. Manuscripts

The manuscripts should be typed in a spacing of IV2 lines with adequately wide margins (left and right). They should be consecutively numbered (including front page and reference list). We recommend the following division:

Front page with title and short title in German and English; author's name, institute name in the native language of the authors. 
Summary and Key Words in German and English. Summaries should not exceed 20 typewritten lines. Summaries should not include any references, tables, figures, references to figures and tables and general statements. Each article should have 3-5 key words.

Text pages should be divided into introduction, materials and methods (optionally patients and methods), results, discussion. Footnotes (with numbers) are placed at the bottom of each page of the text.

Please use abbreviations as economically as possible. Special abbreviations should be written in full when first mentioned followed by the abbreviation in parenthesis, e.g. adenosine-

monophosphate (AMP). Acknowledgements should be placed directly after the text, and before the list of references.

The list of references should include only the publications cited in the text. The references should be numbered according to their

die später verwendete Abkürzung in Klammern folgen lassen: z.B. Adenosin-Monophosphat (AMP).

Danksagungen sollten unmittelbar dem Text folgen und dem Litera-turverzeichnis vorangestellt sein.

Das Literaturverzeichnis soil nur die im Text zitierten Publikationen enthalten. Die Literatur ist entsprechend der Reihenfolge im Text zu numerieren. Es sollen nur Arbeiten, die entweder publiziert oder zur Publikation angenommen sind, zitiert werden. Der Passus «in Vorbe-reitung» oder «persönliche Mitteilung» ist zu vermeiden. Literaturzitate werden mit oder ohne Angabe des Erstautors in den Text eingefügt, z.B. [1] oder Romberg [1] oder Romberg et al. [1].

Zur Abfassung von Literaturzitaten gelten folgende Beispiele:

Darstellungsschema einer Zeitschriftenreferenz:

Kauffman HF, van der Heide S, Beaumont F, Blok H, de Vries K: Class-specific antibody determination against Aspergillus fumigatus by means of the enzyme-linked immunosorbent assay. III. Comparative study: IgG, IgA, IgM ELISA titers, percipitating antibodies and IgE binding after fractionation of the antigen. Int Arch Allergy Appl Immunol 1986;80:300-306. Darstellungsschema einer Buchreferenz:

Hardy WD Jr, Essex M: FeLV·induced feline acquired immune deficiency syndrome: A model for human AIDS, in Klein E (ed): Acquired Immunodeficiency Syndrome. Prog Allergy. Basel, Karger, 1986, vol 37, pp 353-376.

Die Zahl von Abbildungen und Tabellen soil niedrig gehalten werden und darauf abzielen, den Text zu erläutern. Abbildungen werden mit (Abb. 1), Tabellen mit (Tab. 1) in den Text eingefügt. Bereits im Text genannte Zahlen bedürfen keiner Wiederholung in einer Ta-belle. Umgekehrt brauchen die in Tabellen zusammengestellten Zahlen nicht im Text wiederholt zu werden. Farbabbildungen können angenommen werden, bedürfen aber eines Reproduktions- und Druck-kostenzuschusses, den der Autor zu tragen hat. Abbildungsvorlagen sind $3 \mathrm{fach}$ als Papierabzüge einzureichen. Vor-lagen nicht aufkleben, lochen oder mit Büroklammern anheften; auf der Rückseite den Namen des Autors, den Titel des Beitrags, die Angabe, wo «oben» ist, sowie die Bildnummer angeben. Alle Abbildungen und Tabellen sind mit einer Legende zu versehen. Alle Legenden einer Arbeit werden auf einer gesonderten Seite zu-sammengestellt. Die Legenden sind kurz und präzise zu halten und sollen die Abbildungen bzw. Tabellen vollständig erklären. Die Interpretation der Daten erfolgt nicht in der Legende, sondern ausschließ-lich im Text.

Autorenadresse 
Postanschrift des Autors am Schluß der Arbeit vollständig angeben.

3. Umfang von Manuskripten

Originalarbeiten (Gliederung s.o.) sollen 10 Textseiten nicht über-schreiten.

Kurzmitteilungen folgen der Gliederung von Originalarbeiten und sollen 5 Textseiten, 5-10

Literaturhinweise und max. 1 Abbildung und 1 Tabelle (oder wahlweise 2 Abbildungen oder

Tabellen) nicht überschreiten. Schwerpunkte von Kurzmitteilungen sollen neue Er-gebnisse

wissenschaftlicher Arbeiten, auch in Form sogenannter vor-läufiger Mitteilungen, und auch neue Studienansätze - experimentell oder klinisch - sein. Verlag und Schriftleitung wollen erreichen, daß solche Arbeiten innerhalb kürzester Zeit publiziert werden. Selbstverständlich bleibt es dem Autor überlassen, zu einem späteren Zeitpunkt eine ausführliche Fassung einzureichen.

Übersichtsarbeiten folgen nicht der Gliederung von Originalarbeiten. Titelseite, Zusammenfassung und Literaturverzeichnis (s.o.) sind jedoch erforderlich.

4. Kosten und Sonderdrucke

Übersteigen die Kosten der Autorkorrektur 10\% der Satz-kosten, müssen diese dem Autor in

Rechnung gestellt werden. Dem Autor stehen 40 Gratissonderdrucke seiner Arbeit zu.

order of appearance in the text. It is recommended to quote only articles which have been either

published already or accepted for publication.

Please avoid passages like 'in preparation' or 'personal communication'. Quotes from references are inserted into the text with or without the name of the first author, e.g. [1], or Romberg [1] or

Romberg et al. [1]. For references the following examples are compulsory: Outline of a magazine reference:

Kauffman HF, van der Heide S, Beaumont F, Blok H, de Vries K: Class-specific antibody determination against Aspergillus fumigatus by means of the enzyme-linked immunosorbent assay. III. Comparative study: IgG, IgA, IgM ELISA titers, precipitating antibodies and IgE binding after fractionation of the antigen. Int Arch Allergy Appl Immunol 1986;80:300-306. Outline of a book reference:

Hardy WD Jr, Essex M: FeLV-induced feline acquired immune deficiency syndrome: A model for human AIDS, in Klein E (cd): Acquired Immunodeficiency Syndrome. Prog Allergy. Basel, Karger, 1986, vol 37, pp 353-376.

The number of figures and tables should be limited and aim to illustrate the text. Figures are listed in the text as (fig. 1), tables as (table 1). Figures already mentioned in the text need not be repeated in a table. Accordingly, numbers used in tables need not be repeated in the text. Figures in color may be accepted, provided the author is prepared to defray the costs involved.

Do not fasten original figures with glue or paper clips or punch holes in them. Please state on the back the author's name, the title of the article, the 'top' instruction and the number of the figure. All figures and tables must include a legend. All legends should be listed together on a separate page. Legends should be kept short and precise and should illustrate the figures and tables exhaustively. The data should not be interpreted in the legend but exclusively in the text.

Author's address

Please give the author's full address at the bottom of the article.

3. Volume of Manuscripts

Original papers (framework see above) should not exceed 10 text pages.

Short communications adhere to the framework of original papers and should not exceed 5 text pages, 5-10 references and a maximum of 1 figure and 1 table (optionally either 2 figures or tables). Short communications should focus on the results of scientific studies, also in the form of so called provisional reports as well as new scientific approaches either experimental or 
clinical. It is the publisher's and the editorial staff's aim to manage the publishing of such articles within the shortest period of time possible. It goes without saying that the author is at liberty to hand in a complete version at a later date. Review articles do not adhere to the framework of original papers, the title page, a summary and a list of references (see above) are, however, compulsory.

4. Costs of Reprints

The author will be charged for corrections to the galley proofs entailing expenses in excess of $10 \%$ of the original typesetting costs. The author is entitled to 40 free reprints of his or her article.

100

Hinweise für Autoren · Instructions to Authors 